\title{
Improved open-sun drying method for local swamp rice in Uganda
}

\author{
A. Candia', E.T. Oker', J. Lamo', G.L. Obeti', J. Yawe', O.S.E. Adur ${ }^{2}$ O. S. E., A.R. Saasa', \\ J. Muzei ${ }^{1}$, J. Olupot ${ }^{1}$ S. Epiku ${ }^{I}$, W. Okiror ${ }^{I}$ and I. Mutinda ${ }^{I}$ \\ ${ }^{1}$ Agricultural Engineering and Appropriate Technology Research Centre, P. O. Box 7144, \\ Kampala, Uganda \\ ${ }^{2}$ Cereals Program, National Crops Resources Research Institute, P. O. Box 7084, Kampala, Uganda
}

Author for correspondence: alphonsecandia@gmail.com, hugoscand@yahoo.com

\begin{abstract}
"Kaiso" and "Supa" are the main local swamp-rice (Oryza Sativa) varieties currently grown in Uganda mainly by smallholder farmers on small gardens $(0.5$ - 2ha). Due to lack of mechanized drying equipment and owing to the low volumes of their harvests, these farmers use open-sun drying methods, where the paddy is spread on tarpaulins, cemented floors or bare ground. In most cases the paddy is badly dried and is highly fissured. Such paddy on milling contributes to low levels of mill recovery and head rice count of the milled rice. Compared to other varieties and countries, the mill recovery and head rice levels are ostensibly low. The study aimed to improve the above method under the Ugandan weather conditions with a view to increase the mill recovery and head rice levels. Paddy of the predominant "Kaiso" variety was dried in sun on cemented floor at ten depths: control (farmers' method), 30, 40, 50, 60, 70, 80, 90, 100 and $110 \mathrm{~mm}$. The results showed that the best paddy drying depth was between 70 and $80 \mathrm{~mm}$. However at these depths, the paddy takes $7-8$ days to dry. To reduce the drying time, the paddy was first set to dry at $80 \mathrm{~mm}$ depth for two days; after which time, it was divided into three different potions that were further dried at different depths of 80,40 and $30 \mathrm{~mm}$. The results showed that samples whose drying depths were reduced to $40 \mathrm{~mm}$ and $30 \mathrm{~mm}$ took four days to dry while samples whose depths remained at $80 \mathrm{~mm}$ took 7-8 days. There were no significant differences in mill recovery values $(p=0.2968)$ and head rice levels $(p=0.5890)$. Improvement index in mill recovery was 1.14 and that of head rice was 1.24. Average aflatoxin level in the samples whose depth was reduced to 40 $\mathrm{mm}$ was $4.8 \mathrm{ppb}$ and that reduced to $30 \mathrm{~mm}$ was $2.3 \mathrm{ppb}$. From these results, it was recommended that "Kaiso" variety should be dried at $80 \mathrm{~mm}$ depth for two days and drying depth should be reduced between 30 and $40 \mathrm{~mm}$ for subsequent drying. It was further recommended that the method be tested with other swamp varieties before general conclusion is drawn that it can work for all swamp varieties.
\end{abstract}

Key words: Head rice, mill recovery 


\section{Introduction}

Since its introduction to Uganda in 1904 (Odogola, 2006), rice is mainly grown by smallholder farmers in gardens of sizes 0.5 - 2 ha. Kasio (K85) and Supa which are in the group of Oryza Sativa are the two main swamp rice varieties grown in Uganda (Obaa et al., 2012). Probably owing to small farm sizes, smallholder farmers are not willing to invest in improved mechanised technologies for carrying out different postharvest operations, particularly for drying paddy. Farmers spread paddy thinly, in depths of not more than $20 \mathrm{~mm}$, on tarpaulins, cemented floors or bare ground, to dry using sunshine. As it dries the paddy is raked after every one to two hours, and depending on the weather conditions, it takes one to two days to dry. In most cases the paddy is over dried, resulting in high grain fissuring (Odogola, 2006; Obaa et al., 2012). Recent studies have shown that most of the paddy supplied to rice mills, has moisture content levels of 10.3 $-11 \%$ w.b., which is well below the recommended milling moisture content of $12-13 \%$ w.b. for local varieties and fissure levels of $60 \%$ in dry paddy, have been recorded (Candia and Masette, 2012). Such paddy, upon milling, contributes to low levels of mill recovery and head rice in the milled rice (IRRI, 2009). However, mill recovery and head rice are among the important parameters that affect profitability of the rice milling industry. Besides, the potential consumers in urban and peri-urban centres, that offer niche markets, have become increasingly sensitive to food quality. This group of consumers is on the rise in Uganda and prefer good quality milled rice with high levels of head rice (Ahmed, 2012; Masette et al., 2013). Unfortunately, due to small farm sizes, local rice farmers continue to rely on traditional open-sun drying methods for drying their paddy. The purpose of this study was to improve the traditional opensun drying method in Uganda with view to ameliorating mill recovery, level of whole grain and head rice in the milled rice.

\section{Materials and methods}

\section{The drying experiments}

This study was conducted for eight harvest seasons spread in five years from 2010 to 2014 at Doho rice irrigation scheme, Butaleja district eastern Uganda. It started by determining the best paddy drying depth on cemented floor drying structure. This was followed by paddy drying time reduction and ended with comparison of drying on cemented floor and tarpaulin drying structures. The drying experiments for determining the best drying depth were carried out for two years during rice harvesting period of June to August. The paddy used in the experiments was harvested at moisture contents of $25-26 \%$ (w.b) using sickles and threshed by gently beating. In each experiment, the wet threshed paddy was set to dry on cemented floor in the open-sun at ten different profile depths at about $20 \mathrm{~mm}$ (farmers' practice), 30, 40, 50, 60, 70, 80, 90,100 and $110 \mathrm{~mm}$. The paddy was stirred using special wooden racks at one hour intervals and allowed to dry for four hours per day. Thereafter, it was transferred to shed over-night for cooling. The moisture content of the drying paddy was recorded at every stirring interval. Drying was done daily until each drying depth profile reached milling moisture content (12 to $13 \%$ w.b). The dried paddy samples were milled, and mill recovery and whole grain percentage in the 
corresponding milled rice were recorded and plotted as a function of drying depth. The maximum and minimum values obtained from the resultant graphs gave the best and worst paddy drying depths respectively.

After determining the optimum paddy drying depth, the principle of standard drying curve was employed to reduce the paddy drying time. Additional three more drying experiments of paddy were then carried out at the same Irrigation Scheme where best drying depth was determined. These experiments were conducted during the harvesting season of November to February. In these experiments, wet paddy of $250 \mathrm{~kg}$ was set to dry for two days at the best paddy depth profile of $80 \mathrm{~mm}$ depth that was determined in the earlier experiments. Thereafter, it was then divided into three equal parts of: 80 , 40 and $30 \mathrm{~mm}$, and the drying was continued until each sample attained the recommended milling moisture content. The corresponding drying time was recorded. The drying practice was the same as that for determining the best drying depth.

During the drying experiments weather data that influenced the drying process was also collected. These parameters are relative humidity, vapour pressure, wind speed, temperature and sun hours. However, Doho rice irrigation scheme does not have its own weather station to collect all the relevant weather parameters. The FAO New-LocCLIM, 2005 was then used to obtain these parameters (Table 1) for Doho rice irrigation scheme.

\section{Comparison of drying on tarpaulin and cement floor drying structures}

Since most farmers in the country dry paddy on tarpaulin, two sets of drying experiments were conducted on both tarpaulin and cemented floor to compare drying time, mill recovery and head rice level. These experiments were also conducted at Doho rice irrigation scheme on five farms, after reducing the drying time on cemented floor to 4 days which is a fairly manageable level. Wet paddy of $300 \mathrm{~kg}$ was initially set to dry at $80 \mathrm{~mm}$ drying depth on each of the two drying surfaces. These samples were dried for two days and thereafter divided into two equal parts. The drying depth of one part of the sample was reduced from 80 to 40 $\mathrm{mm}$ and the other reduced to $30 \mathrm{~mm}$. They were allowed to dry in a similar way until each attained the milling moisture content.

Table 1. Weather parameters during the drying period

\begin{tabular}{lrrrr}
\hline Weather parameter & \multicolumn{4}{c}{ Months of drying experiments } \\
\cline { 2 - 5 } & \multicolumn{1}{c}{ March } & \multicolumn{1}{c}{ June } & \multicolumn{1}{c}{ August } & \multicolumn{1}{c}{ December } \\
\hline Temperature $\left({ }^{\circ} \mathrm{C}\right)$ & $27.2-32.98$ & $25.98-29.03$ & $25.7-29.1$ & $27.48-32.87$ \\
Relative humidity (\%) & & $58.0-68.5$ & $48.0-57.0$ & \\
Vapour pressure (mm Hg) & $13.28-14.46$ & $14.40-15.16$ & $14.10-14.84$ & $14.08-14.56$ \\
Sun hours (hr) & $4.38-7.04$ & $4.04-6.15$ & $3.21-5.44$ & $4.28-6.50$ \\
Wind speed (m s$\left.{ }^{-1}\right)$ & $2.69-2.71$ & $2.03-2.61$ & $2.19-2.94$ & $2.80-2.84$ \\
\hline
\end{tabular}




\section{Determination of technical performance parameters}

The paddy drying time, mill recovery, head rice level and improvement indices on mill recovery and head rice were the main parameters used for evaluation in this study. Aflatoxin contamination of the paddy was determined to assess the safety of the paddy dried using this method. These parameters were determined using established analytical methods and are described below.

\section{Mill recovery}

About $40 \mathrm{~kg}$ of dried paddy from each drying depth profile was cleaned and later milled using SB 10 mill-top rice mill series (rubber roll type). The pressure of the polishing unit was set to achieve the whiteness degree of milled rice that is usually required by the consumers. The weight of the resultant milled rice obtained was recorded. Mill recovery was computed for each paddy drying depth using Equation (1).

Mill Recovery $(\%)=$

\section{Weight of milled rice $\mathrm{x} 100$ Weight of paddy}

Equation (1)

\section{Paddy drying time}

The paddy drying time was determined by paddy attaining rice milling moisture content (12-13\% w.b.). An electronic hand moisture meter (model Riceter m 401 made by Kett-electric Company in Tokyo, Japan) was used to determine moisture content of the paddy, daily and at hourly intervals during drying. Once a particular drying depth profile reached the milling moisture content (12 - 13\% w.b.), its drying was stopped, packed in gunny bags and taken for storage in a warehouse and placed on wooden pallets. The corresponding drying time in days was recorded.

\section{Head rice}

The head rice and total broken grain amounts in milled rice from each paddy drying depth were determined. Three different samples each weighing $105 \mathrm{~g}$ were randomly taken from the milled rice of each paddy drying depth. Each sample was sorted into head rice and total broken grain; and weighed using OHAUS mechanical triple beam balance, which had three graduated beams and 2,610 g capacity, (made by Fotronic Corporation, Washington, United States of America). The weights obtained were expressed as a percentage of the sample weight. This process was repeated for the other two samples and their average obtained to give the levels of head rice and total broken grain levels in milled rice.

\section{Improvement indices}

The improvement indices of mill recovery and head rice were computed using Equation 2. The baseline values for this study are the mill recovery and head rice data due to farmers' drying practice

$I_{n}=\frac{P_{n}}{B_{n}} \ldots \ldots \ldots \ldots \ldots \ldots \ldots .$. Equation 2

Where: $I_{n}=$ Improvement index of parameter " $n$ "

$P_{n}=$ New value of parameter " $n$ "

$\mathrm{B}_{\mathrm{n}}=$ Baseline value of parameter "n" 


\section{Aflatoxin contamination}

The official method AOAC International (1996) 990.33 (49.217) was used to determine the aflatoxin level in the dried paddy samples.

\section{Data analysis}

This study was divided into three experimental designs. The first design was for determining the best depth at which paddy should be dried. Paddy drying depth (10 treatments) was the only independent factor that influenced mill recovery and whole grain level. Regression analysis was used to understand the relationships between these two dependent variables and paddy drying depth. The second design was for reducing the drying time. Paddy drying depth ( 3 treatments: $80 \mathrm{~mm}$; 80 reduced to 40 and 80 reduced to 30 $\mathrm{mm}$ ) was the only independent factor that influenced mill recovery, head rice and drying time in this design. One-way ANOVA, LSD method was used to compare the means of mill recovery and head rice level obtained from these treatments. The third experimental design, a 2 X 2 CBD was used to compare the performance of the new method on cemented floor and tarpaulin drying structures. Type of drying structure (2 treatments: cemented floor and tarpaulin)) and paddy drying depth ( 2 treatments: 80 reduced to $40 \mathrm{~mm}$ and 80 reduced to 30 $\mathrm{mm}$ ) were the two independent factors that influenced mill recovery and head rice. Two-way ANOVA, LSD method was used in analysing the data from this experimental design. SPSS version 16.0 and MS Excel Computer Soft-wares supported the data analysis and processing.

\section{Results}

\section{Paddy drying depth}

Mill recovery and whole grain level are one of the most important factors that determine profitability of rice businesses. Among others, drying of paddy has substantial influence on them (IRRI, 2009). In this study, the paddy was dried to the recommended milling moisture content, and milled using some of the good rice mill types and polished to consumer taste. The study focused on one variety, grown in the same area under similar water management conditions, and all milling of paddy was done using the same rice mill and at the same milling pressure. The variations in mill recovery and whole grain obtained were therefore mainly due to effects of new method and farmers' method of drying the paddy. Results showed that mill recovery increased from $57.4 \%$ at $20 \mathrm{~mm}$ depth, the control (farmers' method) to a maximum average value of $66.3 \%$ and thereafter declined progressively to $63.5 \%$ at $110 \mathrm{~mm}$ depth (Fig. 1). There was a strong correlation $\left(R^{2}=0.8372\right)$ between mill recovery and paddy drying depth, which is a second order polynomial. A similar trend was also observed with level of whole grain, which increased from $46.2 \%$ at control to an average maximum of $60.3 \%$ and dropped to $53.4 \%$ at $110 \mathrm{~mm}$ depth (Table 2). These results show that there is the best drying depth for paddy using open-sun drying. Considering these results, "Kaiso" variety, should be dried at paddy depths between 70 and $80 \mathrm{~mm}$. 


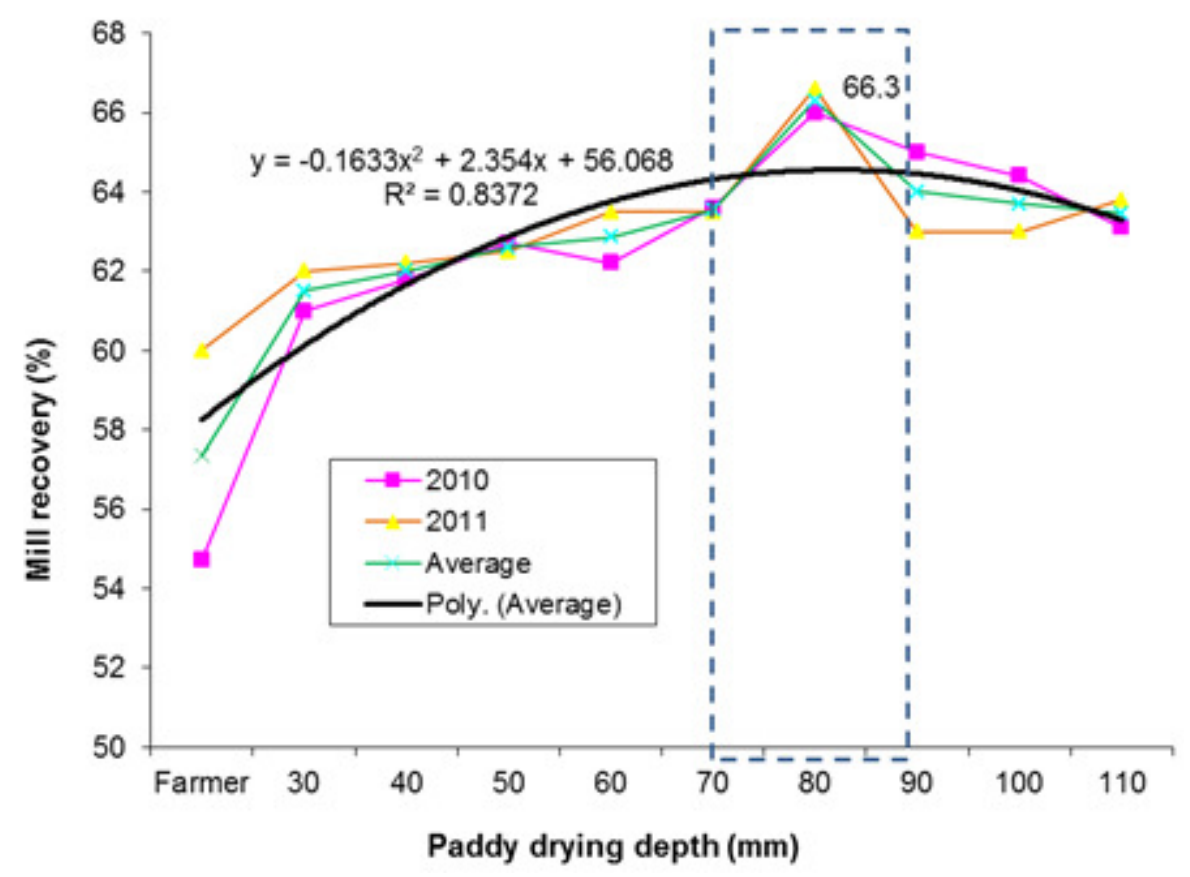

Figure 1. Mill recovery at different paddy drying depths in Uganda

Table 2. Mean whole grain level in the milled rice of experiments for determining optimum drying depth

\begin{tabular}{lrrrr}
\hline $\begin{array}{l}\text { Paddy drying } \\
\text { depth }(\mathrm{mm})\end{array}$ & \multicolumn{3}{c}{ Whole grain $(\%)$} & $\begin{array}{c}\text { Paddy drying } \\
\text { duration (days) }\end{array}$ \\
\cline { 2 - 3 } & 2010 & 2011 & Mean \pm Std & \\
\hline Farmer(20mm) & 39.1 & 53.3 & $46.2 \pm 10.04$ & 3 \\
30 & 53 & 56.6 & $54.8 \pm 2.54$ & 4 \\
40 & 42.9 & 55.6 & $49.3 \pm 8.98$ & 4 \\
50 & 41.8 & 46.1 & $44.0 \pm 3.04$ & 6 \\
60 & 44.8 & 54.5 & $49.7 \pm 6.85$ & 6 \\
70 & 63.9 & 56.6 & $60.3 \pm 5.16$ & 7 \\
80 & 55.7 & 61.1 & $58.4 \pm 3.81$ & 8 \\
90 & 51.8 & 42.9 & $47.4 \pm 6.29$ & 9 \\
100 & 61.8 & 51.7 & $56.8 \pm 7.14$ & 9 \\
110 & 52.9 & 53.9 & $53.4 \pm 0.71$ & 9 \\
\hline
\end{tabular}

\section{Paddy drying time}

\section{Mill recovery}

The above results of mill recovery and whole grain level showed that, "Kaiso" variety should best be dried at paddy depths between 70 and $80 \mathrm{~mm}$ (Fig. 1 and Table 2). At these drying depths the paddy takes 7 - 8 days (Table 2) to reach the milling moisture content. Due to labour demand on farm and risking aflatoxin contamination of the rice due to delayed 
drying, this drying duration is too long for farmers. Experiments conducted to reduce the drying time showed that there was no significant difference in mill recovery from samples dried throughout at $80 \mathrm{~mm}$, dried initially at $80 \mathrm{~mm}$ for two days and reduced to $40 \mathrm{~mm}$ and, dried initially at 80 $\mathrm{mm}$ for two days and reduced to $30 \mathrm{~mm}$. $(\mathrm{p}=0.2968)$. Both samples whose drying depths were reduced from 80 to $40 \mathrm{~mm}$ and 80 to $30 \mathrm{~mm}$ took four days to reach the recommended milling moisture content; while those dried throughout at $80 \mathrm{~mm}$ took $7-8$ days (Table 4 ).

When samples from these three drying depths where paired, no significant differences were observed in the values of the mill recoveries: $80 \mathrm{~mm}$ and 80 reduced to $40 \mathrm{~mm} ; 80 \mathrm{~mm}$ and 80 reduced to $30 \mathrm{~mm}$; and then 80 reduced to $40 \mathrm{~mm}$ with 80 reduced to $30 \mathrm{~mm}(\mathrm{p}=0.520)$; $(\mathrm{p}$ $=0.8740)$ and $(p=0.6271)$, respectively. The results in mill recovery obtained during experiments conducted in February to March 2012 were low as compared to the other results (Table 3 ). The paddy might have suffered from water stress due to water scarcity as Doho rice irrigation scheme was under general renovation by then.

\section{Head rice and total broken grain levels}

The results showed no significant difference in head rice level of paddy dried throughout at $80 \mathrm{~mm}$, dried initially at 80 $\mathrm{mm}$ for two days and reduced to $40 \mathrm{~mm}$, and also dried initially at $80 \mathrm{~mm}$ for two days and reduced to $30 \mathrm{~mm}(\mathrm{p}=0.5890)$. When samples from these three drying depths where paired, no significant

Table 3. Mill recovery levels obtained during drying time reduction

\begin{tabular}{|c|c|c|c|c|c|}
\hline \multirow[t]{3}{*}{ Drying period } & \multirow{3}{*}{$\begin{array}{l}\text { Farm } \\
\text { number }\end{array}$} & \multicolumn{4}{|c|}{ Mill recovery (\%) } \\
\hline & & \multicolumn{4}{|c|}{ Paddy drying depth (mm) } \\
\hline & & 80 & $\begin{array}{c}80 \\
\text { reduced } \\
\text { to } 40\end{array}$ & $\begin{array}{c}80 \\
\text { reduced } \\
\text { to } 30\end{array}$ & $\begin{array}{l}\text { Farmer } \\
\text { practice }\end{array}$ \\
\hline \multirow[t]{4}{*}{ November to December 2011} & Farm 1 & 65.1 & 66.6 & 64.8 & 56.4 \\
\hline & Farm 2 & 66.4 & 65.8 & 65.1 & 55.9 \\
\hline & Farm 3 & 65.5 & 66.7 & 65.7 & 57.1 \\
\hline & Farm 4 & 65.1 & 66.5 & 67.3 & 56.2 \\
\hline \multirow[t]{3}{*}{ February to March 2012} & Farm 5 & 62.2 & 61.0 & 62.2 & 54.2 \\
\hline & Farm 6 & 61.4 & 61.9 & 61.3 & 55.1 \\
\hline & Farm 7 & 62.0 & 61.2 & 61.4 & 53.3 \\
\hline \multirow[t]{2}{*}{ August 2013} & Farm 8 & 64.0 & 66.0 & 64.1 & 58.9 \\
\hline & Farm 9 & 62.7 & 64.4 & 63.9 & 59.2 \\
\hline Average & & $63.8 \pm 1.8$ & $64.4 \pm 2.4$ & $64.0 \pm 2$ & $56.3 \pm 2$ \\
\hline
\end{tabular}


Table 4. Paddy drying time obtained during paddy drying time reduction

\begin{tabular}{|c|c|c|c|c|c|}
\hline \multirow[t]{3}{*}{ Drying period } & \multirow{3}{*}{$\begin{array}{l}\text { Farm } \\
\text { number }\end{array}$} & \multicolumn{4}{|c|}{ Drying time (days) } \\
\hline & & \multicolumn{4}{|c|}{ Paddy drying depth (mm) } \\
\hline & & 80 & $\begin{array}{l}80 \\
\text { reduced } \\
\text { to } 40\end{array}$ & $\begin{array}{c}80 \\
\text { reduced } \\
\text { to } 30\end{array}$ & $\begin{array}{l}\text { Farmer } \\
\text { practice }\end{array}$ \\
\hline \multirow[t]{4}{*}{ November to December 2011} & Farm 1 & 8 & 4 & 4 & 2 \\
\hline & Farm 2 & 7 & 4 & 4 & 2 \\
\hline & Farm 3 & 8 & 4.5 & 4 & 2 \\
\hline & Farm 4 & 8 & 4.5 & 4 & 3 \\
\hline \multirow[t]{3}{*}{ February to March 2012} & Farm 5 & 7 & 4 & 4 & 2 \\
\hline & Farm 6 & 7 & 4 & 4 & 2 \\
\hline & Farm 7 & 8 & 4 & 4 & 3 \\
\hline \multirow[t]{2}{*}{ August 2013} & Farm 8 & 8 & 4 & 4 & 2 \\
\hline & Farm 9 & 8 & 4 & 4 & 3 \\
\hline
\end{tabular}

differences were also observed in the values of the head rice levels: $80 \mathrm{~mm}$ and 80 reduced to $40 \mathrm{~mm} ; 80 \mathrm{~mm}$ and 80 reduced to $30 \mathrm{~mm}$; and then 80 reduced to $40 \mathrm{~mm}$ with 80 reduced to $30 \mathrm{~mm}(\mathrm{p}=$ $0.2214) ;(\mathrm{p}=0.1410)$ and $(\mathrm{p}=0.3845)$ respectively. There was a clear difference in values of head rice levels from farmers' practice $(59.8 \%)$ and the lowest value (73.9\%) for the new method (Fig. 2). Similar results were also observed with the values of total broken grains (Fig. 3).

\section{Aflatoxin contamination}

There was aflatoxin contamination of the milled rice (Table 5). The contamination may have occurred either during the heaping of harvested paddy, or delayed drying due to heavy rains during the earlier experiments or a combination of the two. The highest aflatoxin obtained from the other experiments where no serious rain occurred was $14 \mathrm{ppb}$ and most samples showed values less than $5 \mathrm{ppb}$. Since there was no rain in last experiments, the delayed drying due to heavy rains may have contributed to some of the high aflatoxin levels in the first experiments. However the values of the aflatoxin observed in the rest of the experiments were below the recommended value $20 \mathrm{ppb}$ set by FAO for human food. This, therefore, means that the rice is still safe for human food.

\section{Improvement indices for average mill recovery and head rice level}

The results showed that improvement indices for mill recovery and head rice levels were all above one. The improvement index for mill recovery was 1.14 , while that for the head rice was 1.24 (Table 6). These mean that compared to farmers' practice, for every $100 \mathrm{~kg}$ of paddy dried using the new method, upon milling, a farmer or a rice miller gets additional (or saves) $14 \mathrm{~kg}$ of safe milled rice with head rice quality factor increased 


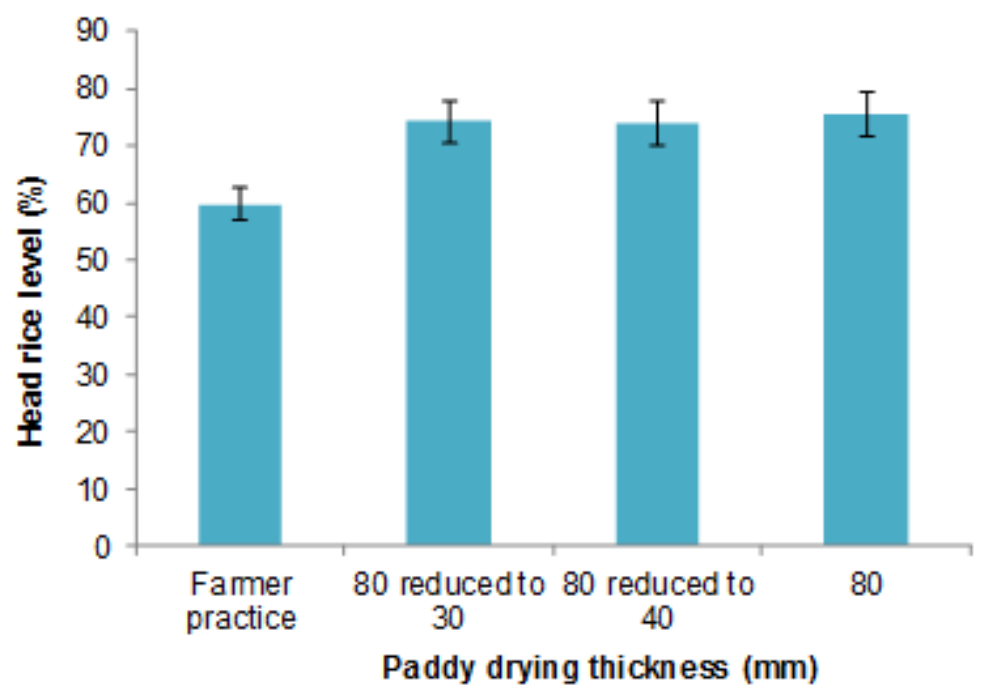

Figure 2. Head rice level obtained during paddy drying time reduction.

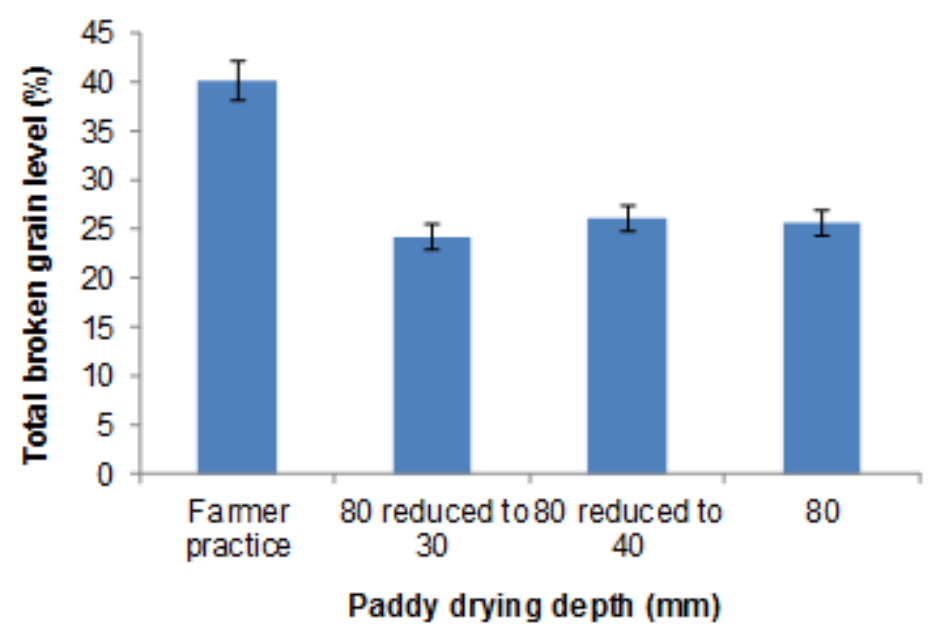

Figure 3. Total broken grain obtained during paddy drying time reduction.

by $24 \%$. Hence, both quantity and market value of milled rice greatly increased per $100 \mathrm{~kg}$ of paddy. This is a tremendous achievement in rice milling business.

\section{Tarpaulin versus cemented floor drying} structures

The results of experiments conducted to compare the performance of tarpaulin and cemented floor showed that there was no significant difference in the values of mill
Table 5. Average aflatoxins contamination in milled rice

\begin{tabular}{lr}
\hline Drying thickness (mm) & $\begin{array}{c}\text { Aflatoxin } \\
\text { levels } \\
\text { (ppb) }\end{array}$ \\
\hline Dried throughout 80 & 11.0 \\
Initially at 80mm then reduce to 40 & 4.8 \\
Initially at 80mm then reduce to 30 & 2.3 \\
Control (farmers practice) & 11.0
\end{tabular}


Table 6. Improvement indices of mill recovery and head rice level

\begin{tabular}{lcccccc}
\hline Parameter & $\begin{array}{c}\text { Farmer } \\
\text { practice }\end{array}$ & \multicolumn{2}{c}{ Improved method } & & \multicolumn{2}{c}{ Improvement index } \\
& & $\begin{array}{c}80 \text { reduced } \\
40 \mathrm{~mm}\end{array}$ & $\begin{array}{c}80 \text { reduced } \\
30 \mathrm{~mm}\end{array}$ & & $\begin{array}{c}80 \text { reduced } \\
40 \mathrm{~mm}\end{array}$ & $\begin{array}{c}80 \text { reduced } \\
30 \mathrm{~mm}\end{array}$ \\
\hline Mill recovery & 56.3 & 64.4 & 64 & & 1.14 & 1.14 \\
Head rice & 59.8 & 73.9 & 74.2 & & 1.24 & 1.24 \\
Total broken & 40.2 & 26.1 & 25.7 & & 0.65 & 0.64 \\
\hline
\end{tabular}

Table 7. Mill recovery of comparative values between tarpaulin and cemented floor

\begin{tabular}{|c|c|c|c|c|c|}
\hline \multirow[t]{3}{*}{ Drying period } & \multirow{3}{*}{$\begin{array}{c}\text { Farm } \\
\text { number }\end{array}$} & \multicolumn{4}{|c|}{ Mill recovery $(\%)$} \\
\hline & & \multicolumn{2}{|c|}{80 reduced to $40 \mathrm{~mm}$} & \multicolumn{2}{|c|}{80 reduced to $30 \mathrm{~mm}$} \\
\hline & & Tarpaulin & Cement floor & Tarpaulin & Cement floor \\
\hline \multirow[t]{3}{*}{ Late October 2012} & Farm 1 & 61.5 & 61.7 & 64.1 & 64.0 \\
\hline & Farm 2 & 61.7 & 63.5 & 64.2 & 60.4 \\
\hline & Farm 3 & 61.3 & 62.1 & 64.5 & 62.9 \\
\hline \multirow[t]{2}{*}{ Mid-August 2013} & Farm 4 & 64.5 & 64.4 & 63.8 & 63.9 \\
\hline & Farm 5 & 62.5 & 66.0 & 63.8 & 64.1 \\
\hline Average & & $62.3 \pm 1.3$ & $63.5 \pm 1.8$ & $64.1 \pm 0.3$ & $63.1 \pm 1.6$ \\
\hline $\mathrm{p}$ & & \multicolumn{2}{|c|}{0.1470} & \multicolumn{2}{|c|}{0.28019} \\
\hline
\end{tabular}

Table 8. Head rice level of comparative values between tarpaulin and cemented floor

\begin{tabular}{|c|c|c|c|c|c|}
\hline \multirow[t]{3}{*}{ Drying period } & \multirow{3}{*}{$\begin{array}{c}\text { Farm } \\
\text { number }\end{array}$} & \multicolumn{4}{|c|}{ Head rice level } \\
\hline & & \multicolumn{2}{|c|}{80 reduced to $40 \mathrm{~mm}$} & \multicolumn{2}{|c|}{80 reduced to $30 \mathrm{~mm}$} \\
\hline & & Tarpaulin & Cement & Tarpaulin & Cement \\
\hline \multirow[t]{3}{*}{ Late October 2012} & Farm 1 & 71.9 & 69.1 & 68.7 & 73.4 \\
\hline & Farm 2 & 75.4 & 77.0 & 81.3 & 77.3 \\
\hline & Farm 3 & 77.8 & 73.4 & 75.7 & 74.7 \\
\hline \multirow[t]{2}{*}{ Mid-August 2013} & Farm 4 & 79.5 & 81.5 & 82.1 & 80.6 \\
\hline & Farm 5 & 73.9 & 83.7 & 82.7 & 76.1 \\
\hline \multicolumn{2}{|l|}{ Average } & $75.7 \pm 3$ & $76.9 \pm 5.9$ & $78.1 \pm 5.9$ & $76.4 \pm 2.8$ \\
\hline \multicolumn{2}{|l|}{$\mathrm{p}$} & \multicolumn{2}{|c|}{0.6421} & \multicolumn{2}{|c|}{0.4289} \\
\hline
\end{tabular}


recovery and head rice levels as shown in Tables 7 and 8. All the samples took the same time of four days to dry.

\section{Discussion}

This study has shown that drying "Kaiso" rice variety at depths of 70 and $80 \mathrm{~mm}$ presented the best mill recovery, whole grain and head rice levels. However, drying the paddy at these depths throughout takes $7-8$ days to reach the milling moisture content (Table 2). This became evident because, paddy dried at these drying depths experienced the lowest fissure level. Farmers are busy on the farm and in their families and, hence, such drying time of 8 days may not be acceptable. As already explained in the earlier sections, the research team therefore continued with the research work to reduce on the drying time. The paddy was initially dried at $80 \mathrm{~mm}$ depth for two days and later the divided into three samples. One sample was kept at $80 \mathrm{~mm}$ and the drying depths of the other two reduced to 30 and $40 \mathrm{~mm}$. Results showed that there were no significant differences in results of mill recovery, whole grain and head rice levels. However, those samples whose drying depths were reduced to 30 and $40 \mathrm{~mm}$ took four days to reach the milling moisture content (Table 4). Considering the gains in mill recovery from 56.3 to $64 \%$ and head rice 59.8 to $74.2 \%$ (Table 6), over their traditional method, such drying time of four days could easily be accepted by farmers.

In Philippines, the recommended paddy drying depth using open sun drying method is only 20-40 mm (IRRI, 2009). In other South East Asian countries such as Indonesia, the highest whole grain level $(56.6-57.5 \%)$ was observed at drying depths of $70 \mathrm{~mm}$ (MAFFJ, 1995), which is almost the same value $(60.3 \%)$ obtained at $70 \mathrm{~mm}$ drying depth during this study. The differences between the obtained results and those of Philippines could be attributed to mainly weather differences. The Philippine's weather during harvesting season is generally hot $\left(31-33^{\circ} \mathrm{C}\right)$ and humid, with vapour pressure of $22.5-23.2$ $\mathrm{mm} \mathrm{Hg}$ (FAO, 2005), making drying difficult. To allow drying of paddy, small drying depths need to be used. The mean air temperatures $25-29{ }^{\circ} \mathrm{C}$, relative humidity of $50-68 \%$ or vapour pressure: 14.10 - $20.7 \mathrm{~mm} \mathrm{Hg}$ (Table 1) experienced in Eastern Uganda during the drying period induces high drying rate, which has devastating effects on mill recovery, and whole grain and head rice levels. To reduce the high drying rate, bigger drying depths have to be used in Uganda as opposed to the smaller drying depths in Philippines.

\section{Conclusion}

Considering the results observed in this study "Kaiso" variety should initially be dried at depth of $80 \mathrm{~mm}$ for two days and thereafter the drying depth should then be reduced to $30-40 \mathrm{~mm}$. It is recommended that this method could then be promoted for "Kaiso" variety and should further be tested with other rice varieties before a wider dissemination is done.

\section{Acknowledgements}

Government of Republic of Uganda, The National Agricultural Research Organization and the Japanese International Cooperation Agency NERICA Promotion Project who supported this research through funding and provision of research facilities. 


\section{References}

Ahmed, M. 2012. Analysis of incentives and disincentives for rice in Uganda. Technical notes series, MAFAP, FAO, Rome, Italy. www.fao.org/3/aat588e.pdf Retrieved on $24^{\text {th }}$ June 2014.

Candia, A. and Masette, M. 2012. Physical quality and safety in selected varieties of local paddy and milled rice processed by cottage millers in Uganda. Uganda Journal of Agricultural Sciences 13(2):147-161.

Food and Agricultural Organization (FAO) New-LOcCLIM 2005: Local Climate Estimator 1.10

International Rice Research Institute (IRRI) 2009. Introduction to paddy drying. Rice Knowledge Bank. http:// knowledgebank.irri.org/rkb/ drying.html\#low Retrieved on $12^{\text {th }}$ February 2014.

Masette, M., Candia, A., Khakasa, E., Okurut, S. and Tinyiro, S. E. 2013. Preferences of Ugandan Consumers for rice varieties and brands on the local market. Uganda Journal of Agricultural Sciences 14(2):1-11.

Ministry of Agriculture, Animal Industry and Fisheries (MAAIF), 2009. Uganda National Rice Development Strategy, 2008-2018. www.jica.go.jp/ english/our_work/thematic issues/.../ uganda_en.pdf. Retrieved on $12^{\text {th }}$ February 2014.

Ministry of Agriculture, Forestry and Fisheries Japan (MAFFJ) 1995. Rice Post-harvest Technology Manual.

Obaa, B., Odur, B., Lamo, J. and Adur, S. 2012. Baseline survey on rice value chain in Uganda for Eastern Africa Agricultural Productivity Project (EAAPP).

Odogola, W.R. 2006. Survey report on the Status of Rice Production, Processing and Marketing in Uganda. www.mofa.go.jp/mofaj/... uganda report.pdf. Retrieved on $24^{\text {th }}$ June 2014.

Uganda Bureau of Statistics (UBOS). 2014. Statistical Abstract. www. ubos.org/onlinefiles/.../ubos/ statistical.../Statistical Abstract 2014. Retrieved on $24^{\text {th }}$ June 2015. 